\title{
Histopathology and Within-Plant Distribution of the Phytoplasma Associated with Australian Papaya Dieback
}

\author{
A. B. M. Siddique, J. N. Guthrie, K. B. Walsh, D. T. White, and P. T. Scott, Plant Sciences Group, School of \\ Biological and Environmental Sciences, Central Queensland University, Rockhampton, 4702, Australia
}

\begin{abstract}
Siddique, A. B. M., Guthrie, J. N., Walsh, K. B., White, D. T., and Scott, P. T. 1998. Histopathology and within-plant distribution of the phytoplasma associated with Australian papaya dieback. Plant Dis. 82:1112-1120.

Dieback-affected papaya plants were characterized by a discoloration of the contents of laticifers, while the anatomy of sieve elements was healthy in appearance until the necrotic stages of the disorder were reached. Laticifer discoloration was not always associated with the presence of phytoplasma in affected tissue, as judged by polymerase chain reaction (PCR) using primers based on the 16S rRNA gene and 16S-23S intergenic spacer region. Phytoplasma DNA was detected in a range of plant tissues, including roots, but not in mature leaves which would act as photoassimilate sources. As plants recovered from a dieback period, the extent of the distribution of both laticifer discoloration and phytoplasma DNA decreased. Phytoplasma cells were not observed in transmission electron microscopy studies of mature sieve elements of dieback-affected leaf, stem, or fruit tissue from plants at various stages of symptom expression, although PCR tests indicated the presence of phytoplasma DNA. Membrane-bound structures, similar in shape and size to phytoplasma cells but interpreted as autophagic vesicles or latex vesicles in immature laticifers, were observed within vacuoles of cells in phloem tissue in leaves displaying tissue breakdown in the form of a water-soaked appearance to veins (" $\mathrm{X}-\mathrm{Y}$ " patterning). In contrast, phytoplasmas were readily observed in papaya leaves displaying symptoms of yellow crinkle. We conclude that phytoplasma cells are present in very low titer in dieback-affected tissues and that, while the plant appears to limit proliferation of the dieback-associated pathogen, this defense strategy is ultimately unsuccessful because it is associated with a rapid decline of the papaya plant.
\end{abstract}

Additional keywords: laticifer, papaya dieback, phloem, phytoplasma

In many diseases of phytoplasmal etiology, phytoplasma cells are present in high numbers within sieve elements in plant tissues with visible external symptoms $(16,21)$. Plant metabolism is evidently disturbed in the near vicinity of the phytoplasma. Curiously, the sieve elements containing phytoplasma often appear normal in structure, while nearby sieve elements that lack phytoplasma may be degenerate $(2,6)$. In other diseases involving phytoplasma, the pathogen is present in very low titer or may not be present within tissues that display external symptoms. For example, phytoplasma cells were observed by transmission electron microscopy (TEM) in young inflorescences of coconut palms, but not in mature inflorescences, leaves, or stems with symptoms of the

Corresponding author: J. Guthrie

E-mail: j.guthrie@cqu.edu.au

Funding support provided by HRDC (grant FR548), CQU and an ARC small grant.

Accepted for publication 25 June 1998.

Publication no. D-1998-0807-03R

(c) 1998 The American Phytopathological Society lethal yellows disease (22). These observations of cell damage at locations distant from the site of the phytoplasma indicate the involvement of pathogen-produced or -induced toxins.

Douglas (6) noted that information on the pathological anatomy of phytoplasma diseases of plants is limited. Certainly, little work has been published on the pathological anatomy of the phytoplasma diseases of papaya. Papaya bunchy top was long thought to be caused by a phytoplasma; however, phytoplasma-specific polymerase chain reaction (PCR) tests failed to detect phytoplasma DNA, while TEM studies demonstrated rod-shaped bacteria in the laticifers of bunchy topaffected plants (3).

Three diseases affecting papaya in Australia, yellow crinkle, mosaic, and dieback, have been demonstrated to be associated with phytoplasma. The infectious agent involved in the yellow crinkle disease was demonstrated to be phloem mobile using dodder transmission experiments (11), and phytoplasma cells were observed by TEM in minor leaf veins of symptomatic leaves (10). In contrast, phytoplasma cells have not been visualized by TEM in mosaicaffected tissues (D. H. Gowanlock, personal communications). Molecular studies
(PCR and restriction fragment length polymorphism [RFLP]) subsequently have detected phytoplasma in both yellow crinkle- and mosaic-affected tissues $(4,8,18,26)$. These studies have not been able to distinguish between the phytoplasma associated with these two diseases, although external symptoms and the titer of phytoplasma, as indicated by TEM studies, are different for the two diseases. The mechanisms by which plant metabolism is disturbed has not been elucidated for either disease.

Attempts to visualize, using TEM, phytoplasma cells or any other etiological agent within dieback-affected papaya tissues have been unsuccessful (13; D. H. Gowanlock, personal communications). Phytoplasmas have been associated with dieback by our group $(18)$ and others $(4,8)$, using phytoplasma-specific primers based on 16S rDNA sequences in PCR. Based on analyses of the $16 \mathrm{~S}$ rRNA gene sequence $(26,27)$ and RFLP analyses of PCR products (8), the dieback-associated phytoplasma is most closely related to the Australian grapevine yellows phytoplasma. However, without demonstrated transmission of the disease, proof of a causative role for the phytoplasma is still lacking.

The typical symptoms of dieback include bunching of crown leaves, bending of the apical growing point, and chlorosis of crown leaves, followed by basipetal necrosis of young leaf and stem tissue (9). Plants with visible external symptoms also exhibit a brown discoloration of the vascular tissues, although not all plants with this internal symptom will develop external symptoms (1). The browning is typically most pronounced on the side of the plant which develops the external symptoms first (the side to which the stem apex bends; 1 ). This discoloration represents a browning of the laticifer contents, which autofluoresce under blue and ultraviolet excitation $(1,13)$. Harding and Teakle (13) also reported the presence of necrotic phloem cells in tissue affected by dieback.

In this study we extend the anatomical observations of Harding and Teakle (13) and Aleemullah and Walsh (1) on the histopathology of the dieback disease of papaya using bright field and transmission electron microscopy, and employ the PCR technique to map the distribution of phytoplasmas throughout the plant body at progressive stages of symptom development. 


\section{MATERIALS AND METHODS}

Plant material: TEM study. Plant materials were collected in October 1996 from a commercial plantation at Yarwun in central Queensland, Australia. The presence of phytoplasmas in plants exhibiting external dieback or yellow crinkle symptoms was confirmed by PCR testing. Vascular tissues from plant parts were examined by TEM, as follows: (i) from an asymptomatic plant: stem, secondary, and tertiary veins of a mature leaf (2 blocks); (ii) from plants displaying dieback symptoms, and from tissues where an adjacent hand-cut section demonstrated laticifer browning and autofluorescence: petiole ( 3 blocks), stem (3 blocks), fruit peduncle (3 blocks), fruit mesocarp (3 blocks), and primary, secondary, and tertiary veins within immature (expanding) leaves (11 blocks), mature leaves with general yellowing ( 20 blocks), and mature leaves with veins having a water-soaked appearance ("X-Y" patterning, as described by Glennie and Chapman; 9) (19 blocks; tissue samples from 9 plants); (iii) from one of the plants displaying dieback symptoms in (ii), petiole and stem adjacent to tissues free of the symptom of laticifer browning and autofluorescence within hand cut sections ( 2 blocks from 1 plant); and (iv) from plants displaying symptoms of yellow crinkle: primary, secondary, and tertiary veins of mature leaves ( 9 blocks of 3 plants).

Yellow crinkle tissue was included as a control for recognition of phytoplasma and sieve elements, given the previous report of TEM observation of phytoplasma within sieve elements (10).

Plant material: Distribution study. Correlated observations on laticifer browning and autofluorescence and the presence of phytoplasma DNA (as determined by PCR testing) in leaf, petiole, fruit, stem, and root tissues were undertaken of three dieback plants collected in May and July 1997 from the Yarwun plantation and a small plot in north Rockhampton, respectively. The first plant was in a very early stage of dieback, as judged by external symptoms (some chlorosis and minor tip bending). The second plant was in a late stage of dieback, as evidenced by the dead crown region and necrotic leaves. The third plant was recovering from a dieback infection, with new leaves and flower buds growing adjacent to the dead crown region.

In a second study, the distribution of phytoplasmas within three dieback-affected plants growing in a small papaya planting in north Rockhampton was examined. Leaf samples consisted of portions of the ends of leaf lobes with midribs up to $2.5 \mathrm{~cm}$, and stem samples were collected using a $0.5-\mathrm{cm}$-diameter cork borer. Tissues were first sampled on 16 October 1997, from plants which appeared to have a bending of the stem tip but were other- wise asymptomatic. Tissues were sampled again after 4 and 26 days. All samples were assessed for autofluorescence of the laticifers, and were screened for the presence of phytoplasma DNA using a stolbur group-specific PCR.

Microscopy. Hand sections of fresh plant material were examined by epifluorescence microscopy to detect laticifer autofluorescence (1). Adjacent tissue was sliced into 2- to $4-\mathrm{mm}^{3}$ pieces and fixed overnight at $4{ }^{\circ} \mathrm{C}$ in a mixture of $4 \%$ paraformaldehyde and $2.5 \%$ glutaraldehyde in $50 \mathrm{mM}$ cacodylate buffer ( $\mathrm{pH}$ 7.2) with $150 \mathrm{mM}$ sucrose and $2 \mathrm{mM}$ calcium chloride. After fixation, tissue was washed with the same buffer three times, then postfixed in $1 \%$ osmium tetroxide in cacodylate buffer overnight. Tissue was washed three times with the same buffer, passed through an ethanol series, and embedded in Spurr's embedding medium. Thick and
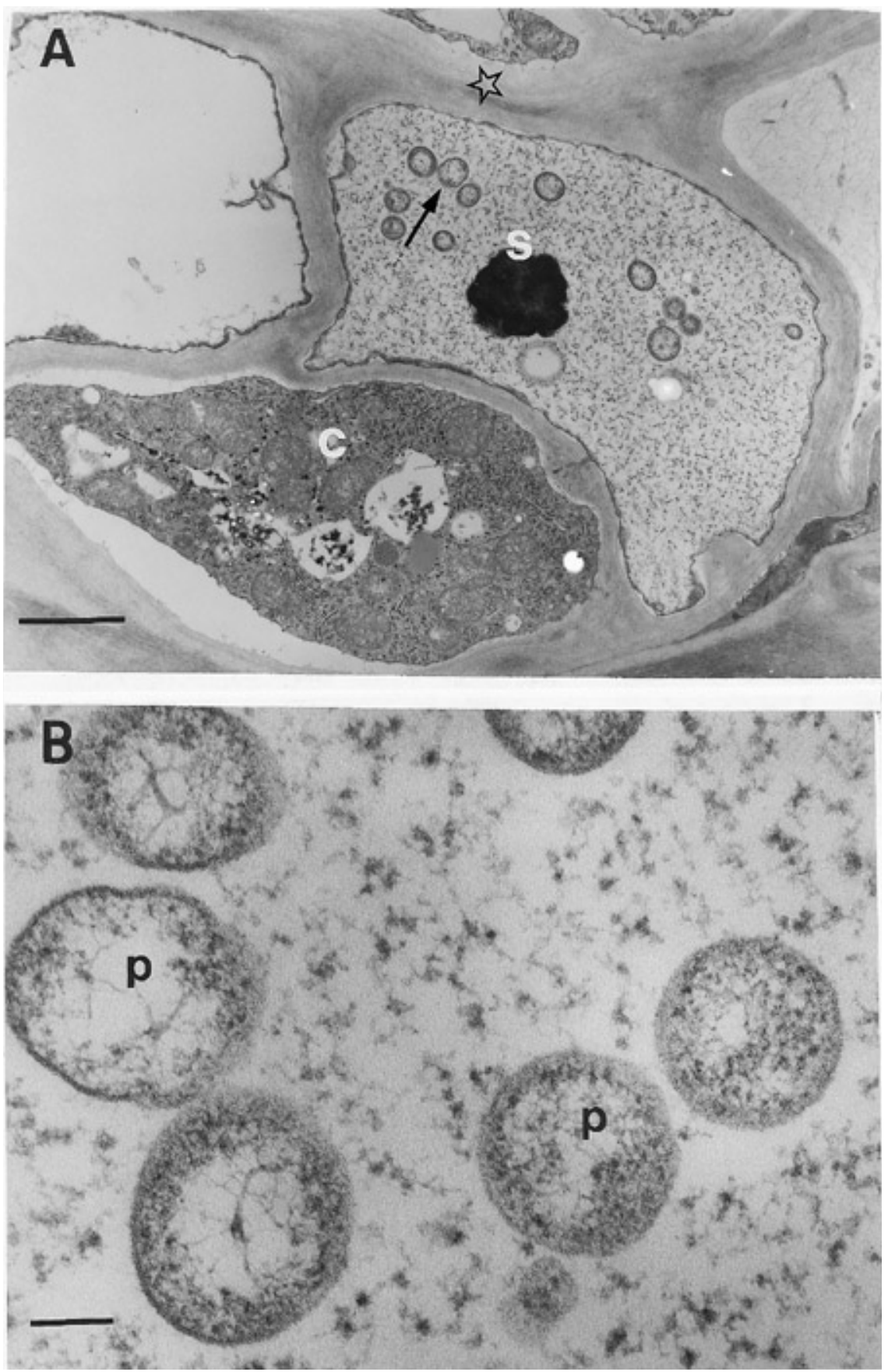

Fig. 1. Transmission electron micrograph of phytoplasma cells within a mature sieve element of the phloem of minor veins of a yellow crinkle-affected papaya leaf. (A) Mature sieve element (S) containing phytoplasma cells (arrow), adjacent to a companion cell (C) containing numerous mitochondria. The sieve cell is characterized by thickened primary cell walls (star) and a cytoplasm occupied by small fibrils (phloem protein). Note plasmodesmata between the sieve element and the companion cell. (B) Phytoplasma cells (p) are characterized by a peripheral cytoplasm containing ribosomes, and a central region of fibrillar material, presumed to contain DNA. Bar represents $2 \mu \mathrm{m}$ in (A) and 0.25 $\mu \mathrm{m}$ in (B). 

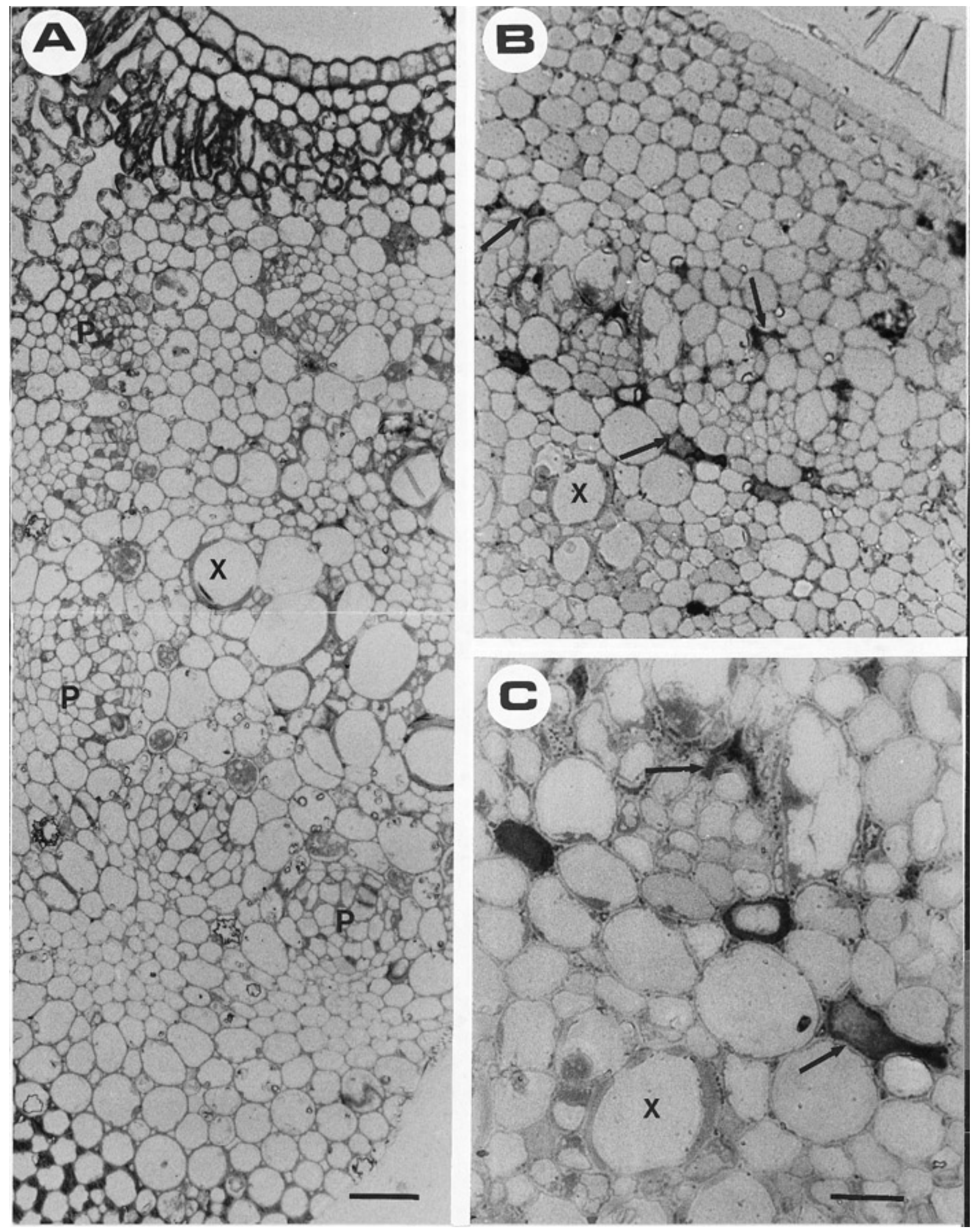

Fig. 2. Bright field micrographs of papaya leaf tissue. (A) Healthy leaf; bundles of phloem (P) adjacent to xylem (X) in a secondary vein. (B) Diebackaffected leaf in which discolored, autofluorescent laticifers were seen in fresh, hand-cut sections. Laticifers (arrows) ramify through the tissue, especially within and adjacent to phloem. Phloem tissue is located adjacent to xylem tissue (X). (C) Magnified image of B. Bar represents $50 \mu \mathrm{m}$ in (A) and (B), and $25 \mu \mathrm{m}$ in (C). 
thin sections were cut from each sample for light and electron microscopy, respectively. Thick sections were stained with toluidine blue. Thin sections were stained with lead citrate and uranyl acetate before observation under a Jeol 101 transmission electron microscope.

DNA extraction and PCR. The method followed in the extraction of total nucleic acids from papaya tissue, and in the use of primers $\mathrm{P} 1$ and $\mathrm{P} 7$ with an annealing temperature of $55^{\circ} \mathrm{C}$ for generic detection of phytoplasma, and the primer pair fU5 and AGY2 for the specific detection of the dieback-associated phytoplasma DNA is described by Guthrie et al. (12).

\section{RESULTS}

Visualization of phytoplasma in yellow crinkle-affected tissue. Phytoplasma cells were observed in the cytoplasm of mature sieve cells within phloem of leaf material displaying symptoms typical of the disease yellow crinkle (Fig. 1A). The yellow crinkle-associated phytoplasmas were round in shape and up to $500 \mathrm{~nm}$ in diameter. These phytoplasma cells were characterized by a single unit outer membrane surrounding ribosome-like granules, and a central nucleoplasmic net of fibrils (presumably DNA; Fig. 1B).

Anatomy of dieback-affected tissue. Other than the internal symptom of laticifer browning, no anatomical changes were observed in the dieback-affected tissues examined using bright field microscopy (in leaf, Fig. 2), compared with corresponding tissues in healthy plants. The areas of tissue necrosis that characterize dieback are anticipated to demonstrate loss of cellular membranes, but these regions were not sampled in the current study. In the TEM study, roughly spherical membrane-bound structures of up to $1,200 \mathrm{~nm}$ diameter were observed in vacuoles of cells within phloem tissue in sections taken from two blocks. These cells were either phloem parenchyma, immature sieve elements, or immature laticifers. One block involved secondary veins of leaves with the "X-Y" patterning symptom (Figs. 3 and 4). The content of the membrane-bound bodies was variable, with some cells containing granular, ribosome-like electron dense particles (Fig. 3), while other bodies were empty (Fig. 4B).

Laticifers were noted throughout the papaya plant body, present in both phloem (Fig. 2) and xylem tissues. As seen in bright field and epifluorescence microscopy, the visible internal browning associated with the dieback disorder was due to a discoloration of laticifer contents (Fig. 2), which was also fluorescent under blue or ultraviolet excitation. As seen in TEM, laticifer cell shape was intact in diebackaffected but not necrotic tissue, and these cells were occluded in parts with an electron dense material, with an apparent loss of latex vesicle integrity (Fig. 5). All sieve
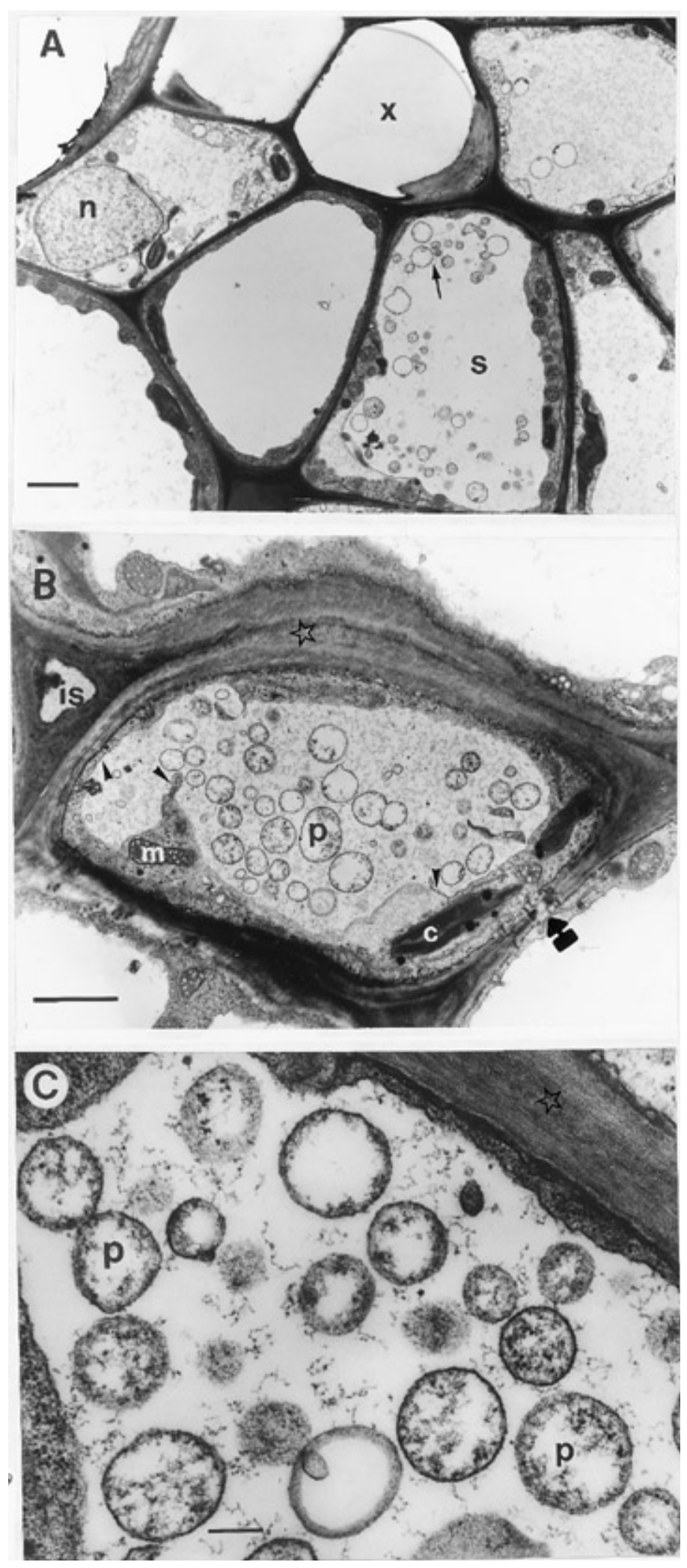

Fig. 3. Transmission electron micrographs of membrane bound bodies within cells of phloem tissue of minor leaf veins displaying the "X-Y" water-soaked vein symptom of the papaya dieback disease (adjacent to tissue depicted in Fig. 2). (A) Mature xylem cell (X) is identified by secondary wall development. Cell containing membrane-bound bodies (arrow) may be either a parenchyma cell, an immature sieve element (S), or an immature laticifer. Similar nearby cell possesses a nucleus (n). (B) Cell containing membrane-bound, phytoplasma-like bodies (p) within a vacuole (tonoplast membrane marked by arrowheads) is interpreted as an immature sieve element or an immature laticifer on the basis of thickened cell walls (star). Thinning of the cell wall at the position of a plasmodesmatal field (arrow) may represent the formation of a pore. (C) Membrane-bound, phytoplasma-like bodies (p) contained within the cell vacuole are bounded by a single membrane. Contents of these bodies are variable, ranging from denser than that of the surrounding vacuole to empty. Bar represents $2 \mu \mathrm{m}$ in (A) and (B), and $0.5 \mu \mathrm{m}$ in (C). 
elements observed appeared healthy (not collapsed).

Distribution of phytoplasma relative to laticifer discoloration. Not all tissues which demonstrated laticifer autofluorescence tested positive for the presence of phytoplasma DNA, and not all tissues which contained phytoplasma DNA demonstrated laticifer autofluorescence. For example, in plant $\mathrm{A}$, with mild tip bending (early visible symptoms of dieback disease), autofluorescence of the laticifers was seen in 11 of 20 samples, including the fruit, an older leaf, and parts of the upper and lower stem tissues (Fig. 6A). Phytoplasma DNA was detected in 13 of the 20 samples. Autofluorescence was not seen in four locations which were PCR-positive (mid-stem, upper stem, and four expanding leaves), while phytoplasma DNA was not
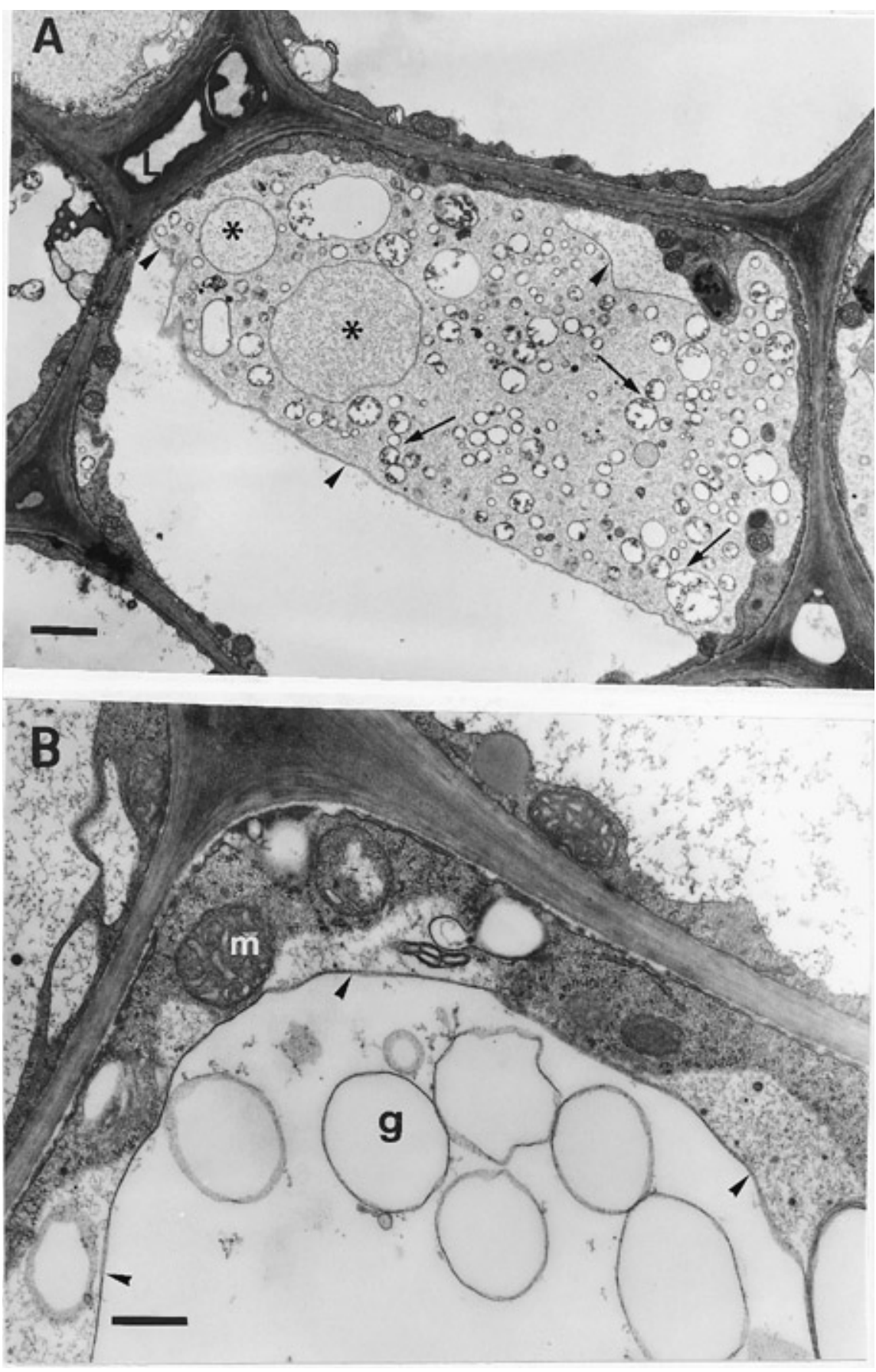

Fig. 4. Transmission electron micrograph of membrane-bound bodies within cells of the phloem of minor leaf veins displaying the X-Y water-soaked vein symptom of the papaya dieback disease. (A) Tonoplast (arrowheads) has parted from the cytoplasm, presumably as a tissue-processing artifact, but showing clearly the localization of the membrane-bound bodies (arrow) within a vacuole. Larger membrane-bound inclusions (asterisks) in the vacuole have different contents to the phytoplasmasized bodies (arrow). (B) Detail of cell containing vesicles which lack inclusions (g) within a vacuole (tonoplast, arrowhead), with healthy mitochondria (m) nearby. Bar represents $2 \mu \mathrm{m}$ in (A) and $1 \mu \mathrm{m}$ in (B).

detected in two locations which showed laticifer autofluorescence (mature leaf and its petiole; Fig. 6A).

In plant $\mathrm{B}$, with tip necrosis, all 16 tissue samples (including root samples) examined had laticifer autofluorescence (Fig. 6B). However, phytoplasmas, as indicated by PCR, were present only in the roots and the immature leaves of the crown (Fig. $6 \mathrm{~B})$. In plant $\mathrm{C}$, which appeared to be recovering from the disease, autofluorescence of the laticifers was restricted to the upper and lower portion of the stem and in the root section taken from the "bent" side of the plant (Fig. 6C). Phytoplasma DNA was only detected in the lower parts of the stem (Fig. 6C).

Distribution of phytoplasma relative to stage of symptom development. In plants with mild tip bending (very early visible symptoms of dieback disease), phytoplasma DNA was detected in expanding leaves, flowers, and the upper stem (Fig. 6A and Table 1). In plants with obvious visible symptoms (crown leaf chlorosis, some apical necrosis), phytoplasma DNA could be detected in the midlower stem (Fig. 6B and Table 1), and even within roots (Fig. 6B). Following death of the stem tip and most leaves, phytoplasma DNA could still be detected in the stem, although the extent of its presence was decreased relative to the preceding stage (Fig. 6C and Table 1). Mature leaves were free of phytoplasma DNA at all stages of the disease progression. Lateral shoot material which grew from the main trunk after death of the upper stem was free of phytoplasma DNA (Table 1).

\section{DISCUSSION}

Electron microscopy visualization of phytoplasma. Gowanlock et al. (10) observed phytoplasma cells within sieve elements of leaves of yellow crinkle-affected papaya plants, using TEM. This observation was corroborated in the present study. The phytoplasma cells associated with yellow crinkle were healthy, as indicated by the presence of structures interpreted as ribosomes and DNA fibrils. The pathogen was limited to cells identified as mature sieve elements on the basis of thick cell walls and the lack of a nucleus.

In contrast, phytoplasma cells were not observed in mature sieve elements of dieback-affected tissues. The only membranebound structures of appropriate size and shape to phytoplasma cells observed in dieback-affected tissue were located within the vacuole of nucleated cells within phloem tissue.

Membrane-bound bodies within vacuoles of phloem parenchyma of Nicotiana rustica infected with aster yellows phytoplasma were tentatively interpreted as degenerate phytoplasma (14). However, Esau et al. (7) and McCoy (19) dispute all reports of phytoplasma cells in vacuoles and parenchyma cells (cells lacking sieve 
pores), respectively. The presence of vesicles within vacuoles was attributed to autophagic activity, and it was noted that phytoplasma cells should be distinguishable from autophagic vesicles on the basis of the size of the ribosomes present in the membrane bound bodies (procaryotic compared with eucaryotic ribosomes; 7). As the inclusions within the membrane-bound bodies were not clearly different from those of cytoplasmic ribosomes (Fig. 3), and as these structures were only seen in vascular tissue displaying the "X-Y" patterning symptom (in tissue beginning to undergo tissue breakdown), we suggest that autophagic activity is a plausible explanation. Alternatively, the membranebound bodies may be latex vesicles within a parenchyma cell beginning to differentiate as a laticifer.

The cellular location of the phytoplasmas detected by the PCR technique within tissue of plants affected by the dieback disease therefore remains unresolved. The organism may be either present in high densities in a very few (sieve element) cells, making it difficult to locate when sectioning, or present in very low densities, making it difficult to distinguish from other cellular inclusions. Immunocytochemistry or in situ hybridization studies at the light microscope level would allow localization in the former case, while immunocytochemical studies at the electron microscope level would be necessary in the latter case. Jones et al. (15) concluded that phytoplasma cells were best viewed by electron microscopy in sections of peach leaves displaying early symptoms of Xdisease, since the numbers of phytoplasma cells decreased as symptom severity increased. We recommend that future attempts to visualize this pathogen using TEM concentrate on tissue in which phytoplasma DNA can be detected, but which does not display external symptoms.

Phloem and laticifer anatomy in dieback-affected tissue. Phytoplasma diseases are often accompanied by anatomical change, culminating in necrosis of phloem tissues. For example, in the Italian grapevine yellows, a flavescence dorée (FD)like disease, sieve elements and the associated companion cells often become necrotic and collapse, and are filled with an osmiophilic material (2). Sieve element degeneration may represent a plant defense strategy, explaining the localized appearance of symptoms in affected vines and the observation of natural symptom remission (2).

However, sieve element collapse is not a universal feature of phytoplasma disease. For example, when Vicia faba plants were inoculated with the FD phytoplasma, root tissues demonstrated high titer without phloem cell collapse or phytoplasma cell degeneration, while shoot tissues demonstrated low titer and sieve element degeneration (17). In our observations, the phloem of dieback-affected tissue was not structurally affected until the point at which the whole tissue became necrotic. This accords with the observation of
Aleemullah and Walsh (1) that the phloem of dieback-affected tissue was functional, as judged by the movement of the symplastic tracer, carboxyfluorescein.

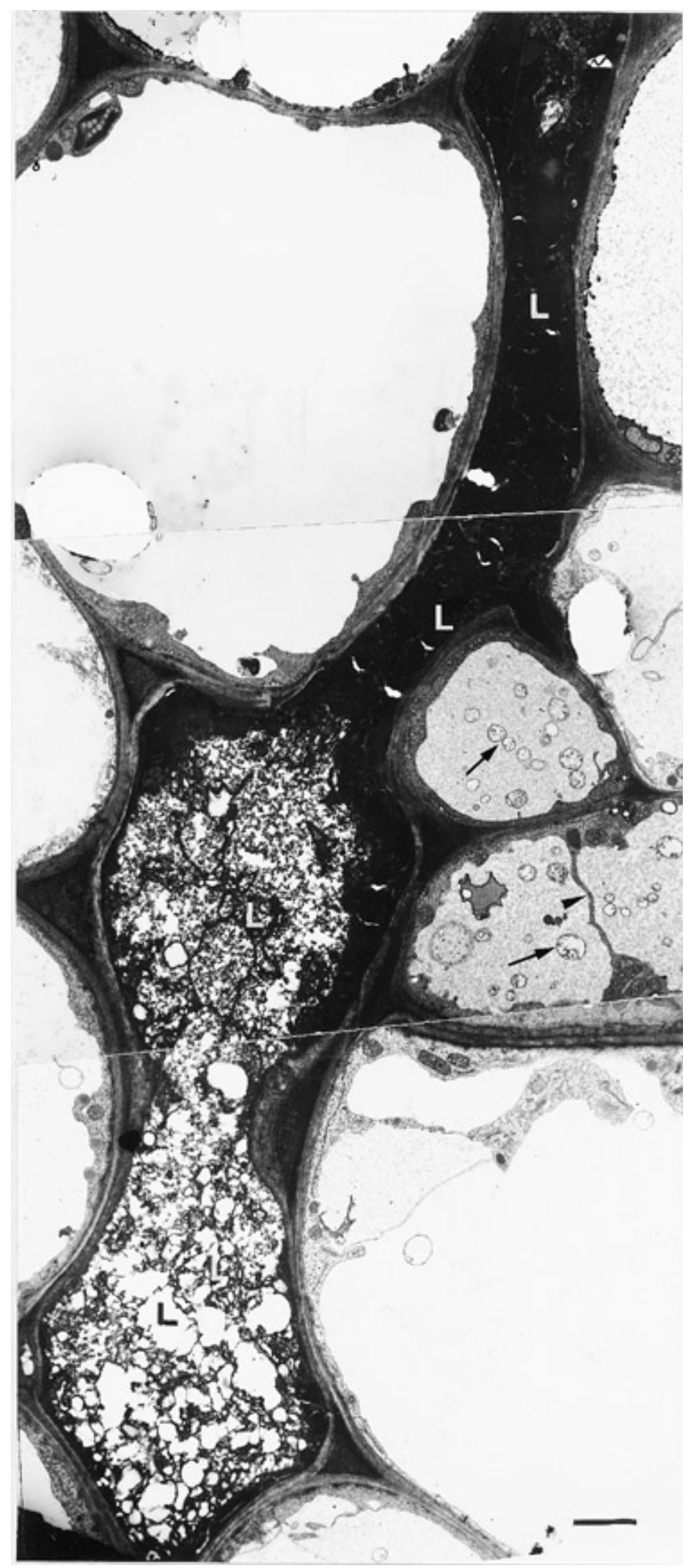

Fig. 5. Transmission electron micrograph of laticifer (L) within phloem tissue of dieback-affected papaya plant, adjacent to cells containing membrane-bound bodies (arrows) within vacuoles. A cytoplasmic bridge through a vacuole is visible (arrowhead). Bar represents $3 \mu \mathrm{m}$. 
In contrast, Harding and Teakle (13) reported necrotic phloem cells in otherwise anatomically healthy appearing tissue. We reinforce the interpretation of Aleemullah and Walsh (1) that the micrograph of "necrotic phloem cells" presented by
Harding and Teakle (Fig. 6 in reference 13) is an image of laticifers within the phloem. Laticifers give the appearance of necrotic cells, being reminiscent of a collapsed cell filled with necrotic contents. However, the laticifers observed in dieback-affected

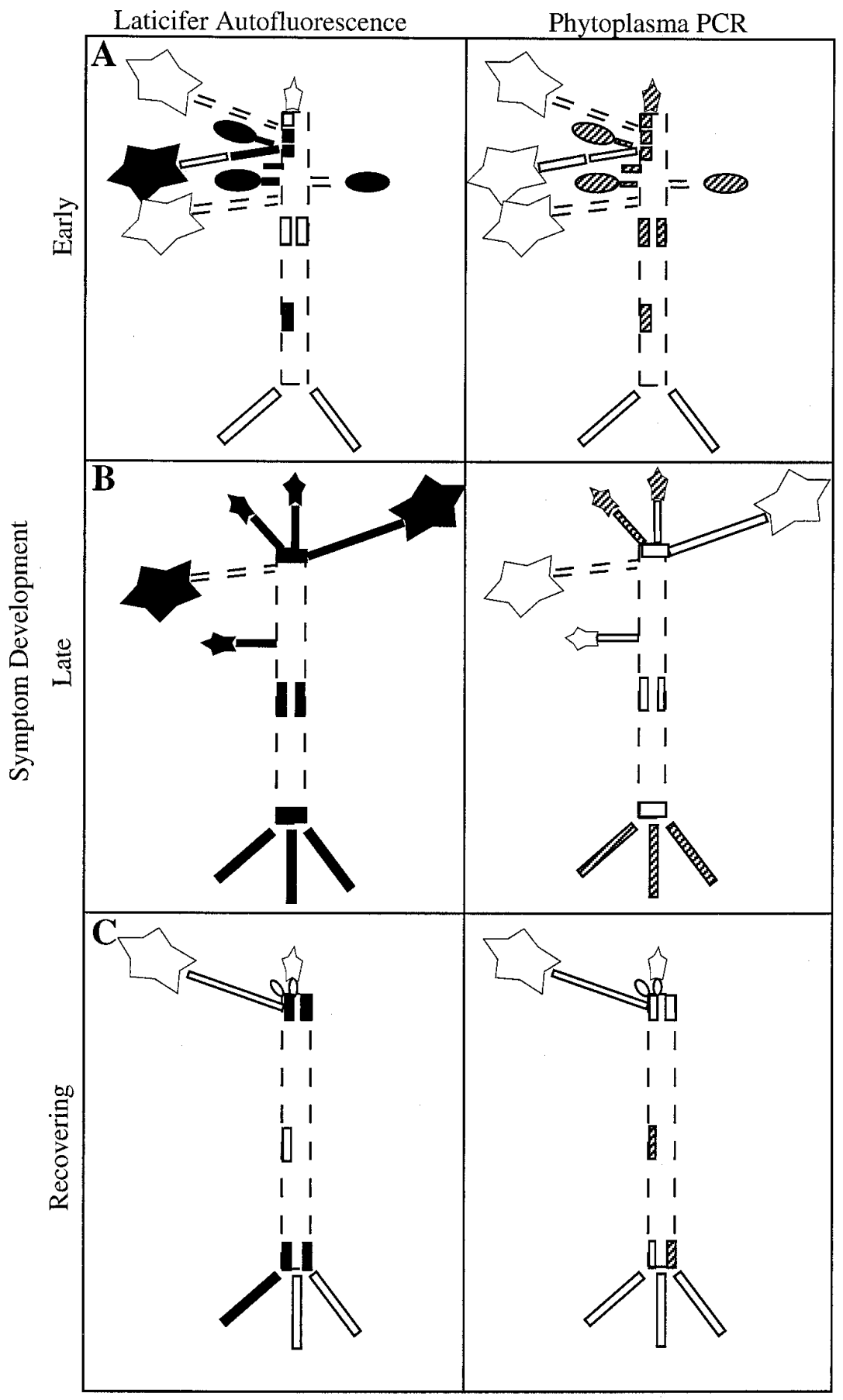

Fig. 6. Diagrammatic representation of the distribution of laticifer autofluorescence (left-hand panels) and dieback-associated phytoplasma DNA, as detected by polymerase chain reaction (PCR) using the primer pair fU5-AGY2 (right hand panels) in three dieback-affected papaya plants. Plants were destructively sampled at three stages of symptom development: (A) very mild stem tip bending; (B) obvious dieback symptoms, foliage yellowing, strong tip bending, some tip necrosis; and (C) following the dieback occurrence, stem tip and leaves dead. Diagram presents a stylized representation of a plant (small stars as immature leaves, large stars as mature leaves, bars associated with stars as petioles, dashed rectangle as stem, ovals as fruit, bars at base of "stem" as roots). Solid lines represent the regions of the plant sampled. Shaded areas represent a positive result (either autofluorescence or a PCR product) while unshaded areas represent a negative result. tissue (Figs. 2 and 5), although discolored as seen in bright field microscopy, were not different in terms of cell shape to those seen in asymptomatic plants.

Laticifers were occluded with an electron-dense (in TEM study), autofluorescent material and suffered an apparent loss of latex vesicle integrity (compare Fig. 5 with micrograph of healthy laticifer, Fig. $5 \mathrm{~A}$ in reference 3 ). These symptoms are also reported for papaya bunchy top disease (3), but are not characteristic of papaya ring spot virus (3), papaya mosaic, or yellow crinkle diseases. Thus, while the symptom is not a specific response to the dieback disease, it is not a "general" stress response.

Phytoplasma DNA was not detected in all tissues displaying laticifer autofluorescence (Fig. 6 and Table 1). We conclude that although laticifer discoloration is a useful indicator of the presence of the dieback-associated phytoplasma in a plant, it is not correlated with the presence of the phytoplasma within a given tissue. Presumably, diseased regions produce a (chemical) signal which causes laticifer discoloration and possibly other symptoms (leaf yellowing, xylem tyloses; 1) throughout other parts of the plant.

Observations on the spread of phytoplasma within the plant body, with reference to organ photoassimilate "sink" status. If phytoplasmas are localized within sieve elements, presumably they will tend to move with the bulk flow of phloem sap, moving generally away from photoassimilate source organs (mature leaves) to sink organs (apices, flowers). Mature leaves are sources of photoassimilate to the plant, typically exporting recently fixed carbon by day and remobilized carbon reserves (starch) by night. This hypothesis is consistent with the report that the phytoplasma associated with lethal yellowing disease of palms has rarely been found (in TEM studies) in mature leaves (22). Similarly, Lherminier et al. (17) used indirect enzyme-linked immunosorbent assay to demonstrate that FD phytoplasmas were present only in the apical part of the plant (point of inoculation) and the roots soon after infection. High titers noted in some sink regions were ascribed to active multiplication, rather than simply passive accumulation. Also, in the current study, phytoplasma DNA was detected in sink areas of the dieback-affected papaya plants, but not in the mature source leaves (Fig. 6).

Speculation on the involvement of a toxin. In phytoplasma diseases involving a high titer of the pathogen, the physiology of the plant may be altered due to physical blockage of the sieve elements by, and resource diversion to, the phytoplasma cells. In other cases, tissue death may result from phytotoxin activity (X-disease of stone fruits and pear decline; 6). The effect of the toxin may be localized to tissues 
near the phytoplasma, with phytoplasma concentration correlated to symptom severity $(5,16)$, or the toxin may be transported within the plant to cause symptom expression at a distance from the location of the pathogen $(20,21)$.

The expression of external and internal papaya dieback symptoms in mature leaves when phytoplasmas could not be detected is consistent with the role of a phytotoxin, produced or induced by the phytoplasma. To reach the mature leaves, this "toxin" must be transported within the xylem.

Selection of tissue for in-field, continuous monitoring of dieback phytoplasma. For diseases such as pear decline (24), apple proliferation (24), ash yellows (25), X-disease (5), and blueberry stunt (23), root tissue is the most reliable, yearround source of material for detection of phytoplasmas. Phytoplasma cells overwinter in the roots and subsequently multiply, re-entering the shoot system via the phloem in spring (5).

In contrast, the dieback-associated phytoplasma was detected in the roots of papaya only at the height of symptom expression, at which stage shoot apical death was imminent (Fig. 6). In a plant recovering from a dieback infection, no phytoplasma DNA was detected in roots. Phytoplasma DNA was not detected in mature leaves, in contrast to leaves which were not yet fully expanded. Immature leaves are sinks for photoassimilate, and therefore destinations for phytoplasmas in the phloem, and may also represent a preferred feeding target for the phloem-feeding insects which are likely to transmit the phytoplasma. Leaf lobes can be sequentially removed with relatively little disturbance to the plant. We have used sequential sampling of immature leaves to estimate the time of infection, as opposed to symptom expression, in a companion study (12).

Conclusion: A description of the disease. We speculate that the dieback-associated phytoplasma spreads through mature sieve elements, following phloem sap flow, but that conditions in the sieve elements of papaya are not conducive to proliferation of this phytoplasma (in contrast to the yellow crinkle-associated phytoplasma, as deduced from the numbers observable by TEM). A hypersensitive response is apparently triggered by the dieback-associated phytoplasma, with host tissue death ensuing. We infer that tissue necrosis results in

Table 1. Distribution of laticifer autofluorescence and phytoplasma DNA as detected by polymerase chain reaction (PCR) using the primer pair fU5-AGY2 within three papaya plants affected by dieback, on three sampling days

\begin{tabular}{|c|c|c|c|}
\hline \multirow[b]{2}{*}{ Tree, sample ${ }^{b}$} & \multicolumn{3}{|c|}{ Day $^{\mathbf{a}}$} \\
\hline & 1 & 5 & 27 \\
\hline \multicolumn{4}{|l|}{1} \\
\hline Crown leaves & $+/-$ & $+/+$ & $\ldots$ \\
\hline Symptomatic crown leaves & $+/-$ & $+1-$ & $\ldots$ \\
\hline Mature leaves & $+/-$ & $+1-$ & $\ldots$ \\
\hline Crown petiole & $+/-$ & $\ldots$ & $\ldots$ \\
\hline Stem apex & $\ldots$ & $\ldots$ & $+/-$ \\
\hline Upper stem & $+/-$ & $+/-$ & $+/+$ \\
\hline Mid stem & $-1-$ & $+/-$ & $+/+$ \\
\hline Lower stem & $-1-$ & $-1-$ & $+1-$ \\
\hline \multicolumn{4}{|l|}{2} \\
\hline Crown leaves & $+/-$ & $+/-$ & $\ldots$ \\
\hline Symptomatic crown leaves & & $+/-$ & $\ldots$ \\
\hline Mature leaves & $-1-$ & $+/-$ & $\ldots$ \\
\hline Crown petiole & $+/+$ & $+/-$ & $\ldots$ \\
\hline Dead immature fruit & $\ldots$ & $\ldots$ & $+1-$ \\
\hline Stem apex & $\ldots$ & $\ldots$ & $+/+$ \\
\hline Upper stem & $+/+$ & $+/+$ & $+/+$ \\
\hline Mid stem & & $-1+$ & $+1-$ \\
\hline Lower stem & $-1-$ & $-1-$ & $-1+$ \\
\hline \multicolumn{4}{|l|}{3} \\
\hline Crown leaves & $+/-$ & $+/-$ & $\ldots$ \\
\hline Symptomatic crown leaves & $\ldots$ & $+/-$ & $\ldots$ \\
\hline Crown petiole & $\begin{array}{l}\cdots \\
+/+\end{array}$ & $\ldots$ & $\cdots$ \\
\hline Mature leaves & $+/-$ & $+/-$ & $\ldots$ \\
\hline Flower & $\ldots$ & $+/-$ & $\begin{array}{l}\cdots \\
\ldots\end{array}$ \\
\hline Stem apex & $\ldots$ & $\ldots$ & $+/+$ \\
\hline Upper stem & $+/+$ & $+/+$ & $+/+$ \\
\hline Mid stem & $-1+$ & $+/+$ & $+/+$ \\
\hline Lower stem & $-1-$ & $-/-$ & $-1-$ \\
\hline Regrowth & $\ldots$ & $\ldots$ & $+1-$ \\
\hline
\end{tabular}

${ }^{a}$ On Day 1 (16 Oct 97), plants exhibited very mild stem tip bending (equivalent to panel A in Fig. 6). On Day 5, the plants displayed obvious dieback symptoms (foliage yellowing, strong tip bending, some tip necrosis) (equivalent to panel B in Fig. 6). The third sampling occurred when stem tip and leaves were dead (equivalent to panel $\mathrm{C}$ in Fig. 6). Test results = autofluorescence/PCR product; positive and negative results (either autofluorescence or a PCR product) are indicated as + and - , respectively; ... indicates data not available.

${ }^{\mathrm{b}}$ Leaf lobes and cores of stem material were collected. the destruction of phytoplasma cells, since the distribution of phytoplasma in the stem decreased with external symptom progression, and leaf samples taken from new lateral shoots of plants which had recovered from dieback tested negative for phytoplasma DNA (this study; 12). With low cell numbers in host tissue, and rapid host tissue death, the dieback phytoplasma is maladjusted for insect vectoring through papaya plants.

\section{ACKNOWLEDGMENTS}

We thank papaya growers D. and $\mathrm{H}$. Hall of Yarwun and F. Aquilizan of Rockhampton for access to field material; D. Gowanlock for encouragement and comment over several years; and the reviewers for their constructive input.

\section{LITERATURE CITED}

1. Aleemullah, M., and Walsh, K. B. 1996. Australian papaya dieback: evidence against the calcium deficiency hypothesis and observations on the significance of laticifer autofluorescence. Aust. J. Agric. Res. 47:371-385.

2. Credi, R. 1994. Occurrence of anomalous mycoplasma-like organisms in grapevine yellows-diseased phloem. J. Phytopathol. 142:310-316

3. Davis, M. J., Kramer, J. B., Ferwerda, F. H., and Brunner, B. R. 1996. Association of a bacterium and not a phytoplasma with papaya bunchy top disease. Phytopathology 86:102109.

4. Davis, R. I., Schneider, B., and Gibb, K. S. 1997. Detection and differentiation of phytoplasmas in Australia. Aust. J. Agric. Res. 48:535-544.

5. Douglas, S. M. 1986. Detection of mycoplasmalike organisms in peach and chokecherry with X-disease by fluorescence microscopy. Phytopathology 76:784-787.

6. Douglas, S. M. 1993. Cytology, histology, and histochemistry of MLO infections in tree fruits. Pages 253-279 in: Handbook of Cytology, Histology, and Histochemistry. A. R. Biggs, ed. CRC Press, Inc., Boca Raton, FL.

7. Esau, K., Magyarosy, A. C., and Breazeale, V. 1976. Studies of the mycoplasma-like organism (MLO) in spinach leaves affected by the aster yellows disease. Protoplasma 90:189203.

8. Gibb, K. S., Persley, D. M., Schneider, B., and Thomas, J. E. 1996. Phytoplasmas associated with papaya disease in Australia. Plant Dis. 80:174-178.

9. Glennie, J. D., and Chapman, K. R. 1976. A review of dieback - a disorder of the papaw (Carica papaya L.) in Queensland. Queensl. J. Agric. Anim. Sci. 33:177-188.

10. Gowanlock, D. H., Greber, R. S., Behncken, G. M., and Finlay, J. 1976. Electron microscopy of mycoplasma-like bodies in several Queensland crop species. Aust. Plant Pathol. Soc. Newsl. 5 (Suppl.) Abstr. 223.

11. Greber, R. S. 1966. Identification of the virus causing papaw yellow crinkle with tomato big bud virus by transmission tests. Queensl. J. Agric. Anim. Sci. 23:147-153.

12. Guthrie, J. N., White, D. T., Walsh, K. B., and Scott, P. T. Epidemiology of phytoplasma-associated papaya diseases in Queensland, Australia. Plant Dis. 82:1107-1111.

13. Harding, R. M., and Teakle, D. S. 1988. Autofluorescence of necrotic phloem cells and laticifers, and a reduced latex flow: new symptoms for papaw dieback disease in Australia. Aust. J. Agric. Res. 39:857-862.

14. Hirumi, H., and Maramorosch, K. 1972. Natural degeneration of mycoplasma-like bodies in an aster yellows infected host plant. 
Phytopathol. Z. 75:9-26.

15. Jones, A. L., Hooper, G. R., and Rosenberger, D. A. 1974. Association of mycoplasmalike bodies with little peach and X-disease. Phytopathology 64:755-756.

16. Kuske, C. R., and Kirkpatrick, B. C. 1992. Distribution and multiplication of western aster yellows mycoplasmalike organisms in Catharanthus roseus by DNA hybridization analysis. Phytopathology 82:457-462.

17. Lherminier, J., Courtois, M., and Caudwell, A. 1994. Determination of the distribution and multiplication sites of flavescence dorée mycoplasma-like organisms in the host plant Vicia faba by ELISA and immunocytochemistry. Physiol. Mol. Plant Pathol. 45:125-138

18. Liu, B., White, D. T., Walsh, K. B., and Scott, P. T. 1996. Detection of phytoplasmas in dieback, yellow crinkle, and mosaic diseases of papaya using polymerase chain reaction technique. Aust. J. Agric. Res. 47:387-394.

19. McCoy, R. E. 1979. Mycoplasmas and yel- lows diseases. Page 229-259 in: The Mycoplasmas, Vol. III. R. F. Whitcomb and J. G. Tully, eds. Academic Press, New York.

20. Nakashima, K., Chaleeprom, W., Wongkaew, P., and Sirithorn, P. 1994. Detection of mycoplasma-like organism associated with white leaf disease of sugarcane in Thailand using DNA probes. Jpn. Int. Res. Ctr. Agric. Sci. J. 1:57-67.

21. Nakashima, K., and Hayashi, T. 1995. Multiplication and distribution of rice yellow dwarf phytoplasma in infected tissues of rice and green rice leafhopper Nephotettix cincticeps. Ann. Phytopathol. Soc. Jpn. 61:451-455.

22. Parthasarathy, M. V. 1974. Mycoplasmalike organisms associated with lethal yellowing disease of palms. Phytopathology 64:667674.

23. Schaper, U., and Converse, R. H. 1985. Detection of mycoplasmalike organisms in infected blueberry cultivars by the DAPI technique. Plant Dis. 69:193-196.

24. Seemüller, E., Schaper, U., and Zimbelmann,
F. 1984. Seasonal variation in the colonization patterns of mycoplasmalike organisms associated with apple proliferation and pear decline. Z. Pflanzenkrankh. Pflanzenschutz 91:371382.

25. Sinclair, W. A., Iuli, R. J., Dyer, A. T., and Larsen, A. O. 1989. Sampling and histological procedures for diagnosis of ash yellows. Plant Dis. 73:432-435.

26. White, D. T., Billington, S. J., Walsh, K. B. and Scott, P. T. 1997. DNA sequence analysis supports the association of phytoplasmas with papaya (Carica papaya) dieback, yellow crinkle and mosaic. Australas. Plant Pathol. 26:28-36.

27. White, D. T., Blackall, L. L., Scott, P. T., and Walsh, K. B. 1998. Phylogenetic positions of phytoplasmas associated with dieback, yellow crinkle and mosaic diseases of papaya, and their proposed inclusion in 'Candidatus Phytoplasma australiense' and a new taxon, 'Candidatus Papaya australasia'. Int. J. Syst. Bacteriol. 48(3):941-951. 